\title{
Letras francesas
}

\author{
LOUIS ARAGON
}

(Especial para ATENEA).

7ien AUIS Aragón pertenece al grupo Surrealiste, y es considerado uno de los escritores jóvenes más interesantes en Francia. Cada una de sus obras nuevas es acogida y comentada en todos los círculos literarios, y hasta los que se encogen de hombros ante las niñerias que acostumbran los surrealistas,-manifiestos, injurias, ataques a latigazos y puñeles a los que no son de su opinión, etc.-admiran su talento.

Las ediciones de la Nouvelle Revue Française acaban de dar el último libro de Aragón. Le paysan de Paris. Esta obra, publicada ya en folletin en la Revue Européenne, habia hecho sensación. Tener en mano el libro, leer el conjunto, nos desilusiona un tanto: el defecto mayor de Le paysan de Paris es su falta de cohesión. su descoyuntamiento, que, en folletin, no se notaba. Pero es sumamente interesante. pues alli Aragón se muestra al desnudo, con su extraordinaria movilidad, su riqueza. pero riqueza tanto de préstamo como personal, y una inquietud que nos deja suspensos: cuando Aragón se libre de tanto elemento postizo, cuando haya, al fin, entre mil posibilidades brillantes, elegido la que esté más de acuerdo con su temperamento. ¿qué nos dará? ¿Obras maestras o sin legitimo valor? Dificil es preverlo.

Abramos juntos el paysan de Paris. La cantidad de escritores 
e influencias que se advierten a cada paso es desconcertante en un soil-disant revolucionario... El primero que se nos impone es... Gómez de la Serna... No olvidemos que Aragón es de origen español. Lo mismo que de la Serna, escribe sobre el café, el circo, el cine, los senos, los hoteles, etc., una serie de comentarios humorístico-sentimentales. Aragón elige como núcleo de la primera parte de su libro un Pasaje del cenlro de París. y nos describe minuciosamente todas las tiendas, negocios. hoteles. calés, peluquerias, teatrillos. paragüeriạs, casas de citas. que alli se encuentran. Actitud de paysan de Paris, de hombre que mira las cosas asombrándose. como si las viera por primera vez, y se detiene largamente a contemplarlas. Esos pasajes le parecen ellamados en forma lurbadora pasajes, como si en esos sitios cerrados a la luz nadie pudiera detenerse más de un instante... Cada tienducha es pretexto de derroches de imaginación, una palabra basta a veces para lanzarlos en un poema en prosa; asi, ante el peluquero. la palabra erubios: «Rubio como - la histeria, rubio como el cielo, rubio como el cansancio. ru- bio como el beso. Sobre la paleta de lo rubio, pongo la - elegancia de los automóviles, el olor de los henos, el silencio - de la mañana. las perplejidades de la espera. los estragos del - rozar. QQué rubio es el ruido de la lluvia. qué rubio es el - canto de los espejoslı. Etc. elc. Eso va demasiado largo. No saber detenerse a tiempo, no elegir entre cien ideas, las diez mejores, es uno de los defectos de Aragón. Otro de sus procedimientos: deformar los objetos usuales hasta trasformarlos en elementos de ensueño. tal como obra, en sus cuadros. el pintor suprarealista Max Ernst. Ahora bien, puede ser que Aragón sea el que influencie a Max Ernst. Además, por su afición a las visiones macabras, y por su predilección por las rameras, por frases como la que citaremos en francés, para que conserve todo su sabor, y su ritmo revelador. Aragón nos recuerda extraordinariamente a... Baudelaire: .Je rêve d'un peuple doux et cruel, d'un peuple chat amoureux de ses grilles et toujours prêt à Taire chavirer ses yeux et ses scrupules, je rêve d'un peuple changeant comme la moire et toujours talonné par l'amour.... 
En la última parte del libro, se sentiment de la nature aux Buftes Chaumonto se pone más en evidencia que al principio el tono apasionado que usa Aragón, y, entre imágenes espléndidas, suelen asomar cierlos pompierismos... Aquel suprarealista es el último romántico... Por lo demás. Aragón es personalmente todo un personaje de Dumas hijo: agriado contra la sociedad por ser hijo natural... Como si en Paris, ciudad libre y por excelencia sin prejuicio, se le ocurriera a persona alguna echar en cara a un hombre su nacimiento...

Somos quizás demasiado exigentes con Aragón, nos bastarian páginas admirables como las hay en Le paysan de Paris para consagrar a un hombre gran escritor. y a él le regateamos los elogios: le guardamos rencor por no mantenerse siempre a la altura de sí mismo. no por falta de talento. sino que por humoradas y caprichos. Hay en eLe sentiment de la nature aux Butles Chaumonts páginas extraordinarias que debe conocer quien se interesa por la literalura contemporánea. Tales los deslumbradores párrafos sobre jardines, sobre la noche, el deseo. el vértigo. las estatuas, el amor, etc. Cuando sueña. Aragón es admirable. Pero tiene la manía de caer en metafisico. y piensa mal. Por eso. quizás, una de sus piezas mejor eréussies, es una divagación publicada por la revista Commerce (no es ésta una revista comercial, como lo pudiera hacer suponer su nombre, sino una de las revistas literarias más arislocráticas y refinadas en Europa: como que la dirigen Paul Valéry. León Paul Fargue, y Valery Larbaud) cuyo titulo es sUne vague de rêve. Comienza así: Il $\mathrm{m}$ 'arrive de perdre soudain tout le fil - de ma vie: je me demande, assis dans quelque coin de l'uni- vers, prés d'un café fumant et noir. devant des morceaux - polis de métal, au milieu des allées et venues de grandes - femmes douces. par quel chemin de la folie j'échoue enfin - sous celte arche, ce qu'est au vrai pont ce qu'ils ont nommé - le ciel.... Es una apologia del suprarealismo. Muy bien. Pero entonces ¿por qué alli también encontramos a ese innovador tan obsesionado por los clásicos franceses que su ensayo termina, a pesar de pretender ser escrito en prosa, ritmado en clásicos 
https://doi.org/10.29393/At10-401MALF10401

502

A tenea

alejandrinos? Para mayor claridad, nosotros los vamos recortando: - Mais entre tous les airs que parfois je fredonne,-il en est un - pourtant qui me donne aujourdhui-une libre illusion du prin- temps et des prés,- - une illusion de la liberté véritable.-Cet - air, je l'ai perdu, et puis je le retrouve...

.C'est qu'il rêve, et je rêve, emporté je rêve.... .Je rêve diun long rêve où chacun rêverait.... $\mathrm{Y}$ termina así:

-Qui est là? Ah très bien: faites entrer l'infini. . Este verso pudiera ser de Victor Hugo, pero también de Edmond Rostand...

Es de un suprarealista...

MARCELLE AUCLAIR. 